\title{
CHRIS KYLE AS A HERO IN AMERICAN SNIPER: A STUDY OF POPULAR LITERATURE
}

\author{
Ruliatul Fatimah \\ Department of English Teaching, IKIP PGRI MADIUN, Indonesia \\ rulieatul88@gmail.com
}

\begin{abstract}
The purpose of this research is to describe the portrayal of hero and heroic mode in the American Sniper movie and explain the reason of hero and heroic mode are represented in the American Sniper movie. The researcher uses popular literature in this study. The research method is descriptive qualitative research. There are two sources of the data; they are primary data and secondary data. The primary data of this research is taken from American Sniper movie. Meanwhile, the secondary of this research are from references from other source which are related to the popular literature. The technique of collecting data is by using documentation. The content analysis is chosen to analyze the data. The result of the research is described as follows: 1) The portrayal of hero has already happened in the previous time, but the heroic mode of hero's mentality as a husband and father who love his wife and his family as it is shown in American Sniper movie is one of new version which does not happen in the previous time. 2) It shows that the movement of action war movie from time to time reflects the audiences' interest or the movie lovers to the action war movie. So, it is the motivation for the Hollywood production to continuously create the newest hero movie to fulfill the market request.
\end{abstract}

Key Terms: Populal Culture, Popular Literature, Hero, Heroic mode, Navy seal, Movie

\section{INTRODUCTION}

American Sniper movie produced by Warner Bros in 2014 is chosen by the researcher to be analyzed. The movie is very popular and liked by movie lovers because the story of the movie is very inspiring. It is about hero who kills many terrorist and performs as United States Navy SEAL who defends the truth in Iraq war. The story is based on true story about the member of United States Navy SEAL. His name is Christopher Scott "Chris" Kyle. He is the most lethal sniper in U.S. military history with over 160 people killed officially.

The story of this movie is adopted from Iraq war which is led by Saddam Hussien with little bit difference from reality. In reality, United States against Iraq because there is a weapon conflict between United Stated and Iraq in 2003. United States accuses Iraq makes

Weapons of Mass Destruction (Buzzanco, 2008). Because of it United States wants to 
identify, isolate, and eliminate Weapons of Mass Destruction. In fact, United States can not prove that Iraq makes a Weapons of Mass Destruction. After United States can not prove, United Stated does not leave Iraq quickly. United States keep against Iraq in Iraq War.

Meanwhile, American Sniper tells about terrorist from Al-Qaeda which is led by Abu Musab al-Zarqawi. In this movie, it is told that United States helps Iraq to find, catch, kill, and bring out the terrorist from Iraq country. The movie becomes controversy because it is reputed as United States Propaganda. This movie is released after ISIS and Al-Qaeda threat are booming. Eventhough the story is different from reality, the movie is very interesting. It shows the struggle of hero to kill a terrorist. Besides, the main character shows the big nationalism. Whether or not this hero deals with the war between America and terrorism is challenging to find.

Besides, as a hero who has big nationalism to his country by keeping the world from terrorist. He performs as United States Navy SEAL who defends the truth. He can kill many terrorists in Iraq war. Besides, he is also good friend who protect his friend from enemy. When his friend is killed by enemy, he has more spirit to fight the terorrists. Eventhough he has duty as United States Navy SEAL, he still keeps in touch with his family by contacting his family. This is a unique fact that job does not affect someone in caring about his family. It shows what kind of hero he is.

Based on the explanation above, it is interesting to analyze further about the potrait of hero and heroic mode seen in the American Sniper movie. Besides, the researcher wants to know why hero and heroic mode are represented in the American Sniper movie. This case is very interesting to be analyzed. It will be explained more in this study. The researcher focuses on the member of United States Navy SEAL as hero which is reflected at the main character of Chris Kyle in Amrican Sniper movie.

\section{METHOD}

This research uses qualitative method to complete the study. Qualitative method is research that does not use statistics but description of a phenomenon or event. The researcher use the descriptive research because all data which are gotten by the researcher are presented in descriptive written. According to Bodgan and Biklen (2007: 05) "Qualitative research is descriptive. The data collected take the form of words or picture rather than numbers. The 


\section{English Teaching Journal, Vol. 4 No. 1, Juni 2016}

ISSN: 2338-2678

written results of the research contain a quotation from the data to illustrate and substantiate the presentation". The reseacher adopts photographs and conversation note in a movie. Then the discussion can be brought on the explanation or description. The researcher uses two types of data source, the primary and secondary data. The researcher takes movie entitled American Sniper produced by Warner Bros as the primary data. While the secondary sources are taken from books, articles, dissertation and websites that related the analysis of Chris Kyle as a hero in American Sniper. The researcher takes collecting or documentation as technique of collecting data. "Collecting refers to the compiling or accumulating of objects (documents, artifacts, and archival record) related to study topic" (Yin, 2011: 147). The researcher analyzes the data by using content or document analysis. Holsri (in Berg, 2001:240) states that content analysis is the technique to make conclusion by systematically and objectively identifying special characteristics of messages.

\section{RESULT}

To begin with the primary data, the following is the portrayal of hero and heroic mode seen in the American Sniper movie. The researcher uses action war genre movies and focuses on the hero. Adi (2008: 88) states that "action war movie more emphasized in action hero rather than the element of the war itself." It means that action war movie focuses on the actions of hero in their missions. In action war movie, the researcher focuses on the war which has relationship with the real war in the past time. Almost all the action war movie involves United States country and other countries in Middle East, such as United States and Iraq. It takes involvement much in politics, instead the Security Council of PBB member which has responsibility to guard the world safe. This involvement permits United States taking a part to safety issue. Even, it is in war.

In the Hollywood movie, there are many movies to be categorized to action war movies. Action war genre movies are quite interesting to the society. Many people liked and discussed it. According to Adi (2008: 88), action war movies more liked by people because it has action element. There are many problems, purpose in every Hollywood movie, especially in war action movie. To create a Hollywood movie some creator should observe something happen in the world. United stated has an important role in the world. For example, when war happens in another country, United Stated will send their army to help that country. There are 
many movies that show the role of United Stated in another country, such as American Sniper movie.

Besides American Sniper movie, there are many movies which have similarity with American Sniper movies, such as Rambo (1985), Platoon (1986), Clear and Present Danger (1994), Saving Private Ryan (1998), The Hurt Locked (2008), and Lone Survivor (2014). All the movies are categorized in action war movie so the movie is about a struggle of hero in a war.

The action war movie of Hollywood movie has a relationship with the real war in the past time. According to Karki (2011: 680), many people observe and take speculation that around Hollywood's representation of the hero as American people's fantasy of the U.S. experience in Vietnam War. It means that hero movie has a relationship with past time story. Some story is taken from the struggle of people in the Vietnam War in 1965.

Vietnam War can be said as a black note for the United States because the United States lost from Vietnam. Many of United States soldiers die and get injured. But the most interesting in industrial movie maker is sometimes Hollywood creates a movie which has a relationship between Vietnam War, such as Rambo and Missing in Action. In every movie has a different characteristic, such as propaganda of United States, Non- Propaganda, and entertain the reader. Rambo which has propaganda of United States in the story, Missing In Action which has a purpose of entertaining the reader only, and another movie.

\section{The Portrayal of Hero and Heroic Mode From Time to Time}

The movement figure of hero from time to time. The Rambo (1985) the figure of hero from an ordinary person who has big muscle and strong body, while Platoon (1986), Clear and Present Danger (1994), Saving Private Ryan (1998), The Hurt Locked (2008), and Lone Survivor (2014) the figure of hero is from United States army. It means that after 1985 the figure of the hero change became a member of United States army until 2014. As United States army, he has good and strong body because to be a member United States army should has good and strong body. Because they always do exercise to keep their body.

The purpose of the mission of hero from time to time have many version. The purpose of the mission in Rambo (1985) is to help United States army who was prisoned by Vietnam soldiers in Vietnam War. Eventhough as an ordinary person, he can help the 


\section{English Teaching Journal, Vol. 4 No. 1, Juni 2016}

ISSN: 2338-2678

United States. While the purpose of the mission in Platoon (1986) is to fight the enemy from North Vietnam in Vietnam War. Beside that the he also has a conflict with his two sergant who has different opinion. Based on the both movie, the purpose of the mission there is change but in the same situation in Vietnam War.

The purpose of the mission in Saving Private Ryan (1998) already happen in the past Rambo (1985). It means that both of the missions there is no change. The purpose is to save the soldier from the United Army who imprisoned by German army in World War II. While the purpose of the mission in The Hurt Locked (2008) is to find and domisticate a bomb in Bagdad after Iraq War happen. The purpose of the mission in Lone Survivor (2014) are track and kill the leader Taliban Ahmad Shah during the war in Afganistan. But this mission is failed because Taliban soldiers attack them quickly. The mission of both movies has change from the past. It means that in 2008 until 2014, the purpose of the mission is more variative and creative.

The mentality of Rambo (1985), Platoon (1986), Clear and Present Danger (1994), Saving Private Ryan (1998), The Hurt Locked (2008), and Lone Survivor (2014) there is no change from time to time. All the heroes from the movie show as hero who has big nationalism to his country and also as a good friend who care and protect their friend.

\section{The Portrayal of Hero and Heroic Mode Seen In The American Sniper.}

The hero can be described as having masculine characteristics of strong and muscle body while carrying out their heroic missions. Usually the enemy is very powerful so as the hero he should have a strong and muscle body to fight them. The hero who has strong and muscle body in American Sniper movie will show in data below:

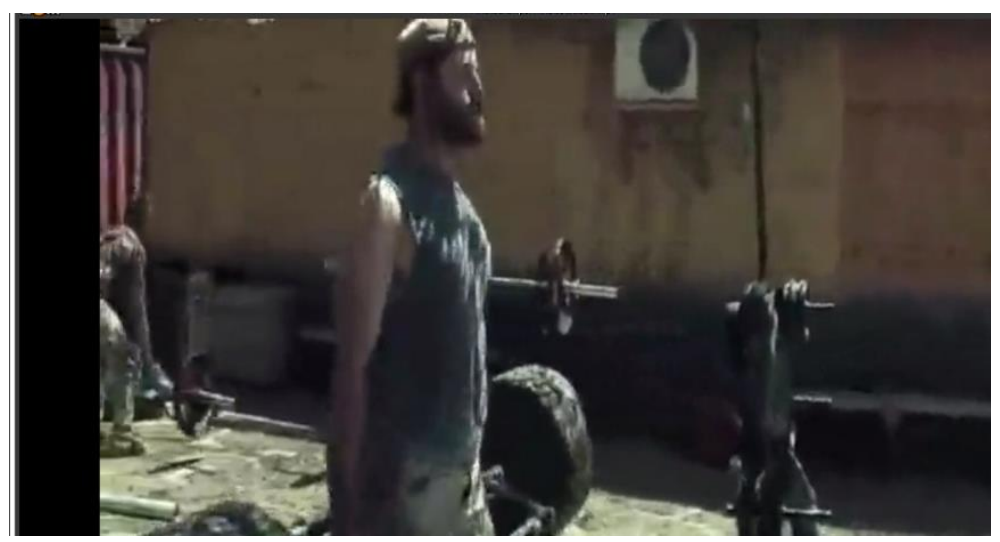

Figure 1 : The strong body of Chris Kyle. 
Figure 1. at 00:50.42- 00.50.56 illustrates that Chris Kyle as a hero who has a masculine character. He has tall, big, strong, and muscle body. This picture also shows that as the hero he does a physical exercise in the camp of United States army in Iraq. It shows that to be a member of Navy SEAL, it is better to have a strong and muscular body. In American Sniper, Chris Kyle kills many of terrorists. One of them is the sniper of AlQaeda. His name is Mustafa.

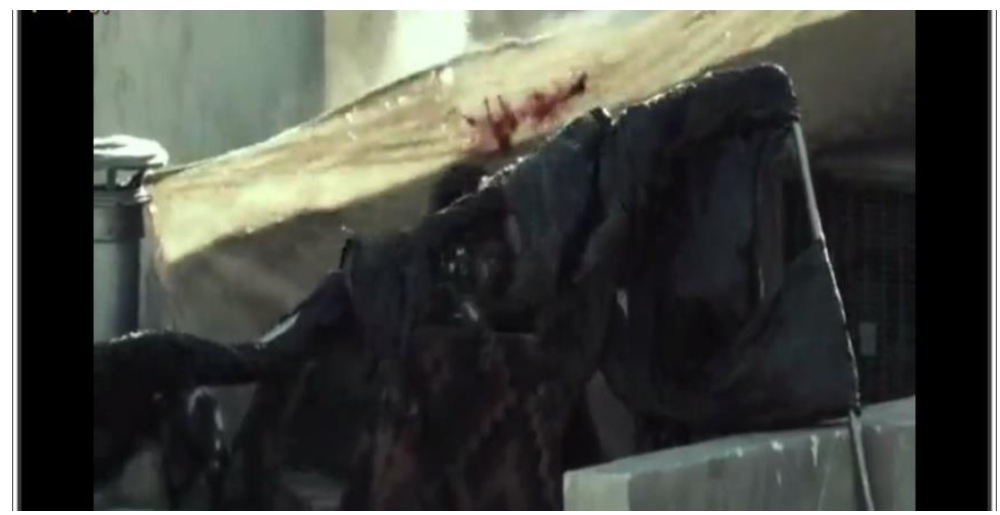

Figure 2.: The death of Mustofa in fourth tour.

Figure 2. at 01.43.52-01.44.02 shows that the sniper Al- Qaeda (Mustafa) is killed by Chris. He shoots him within 1.900-meter distance. It is impossible to shoot people by 1.900 distances. For the sake of Biggless, he can do it. Chris and his friends are very happy.

Eventhough Chris is as member of Navy SEAL who is very busy in his job, he still care to his wife. Even in danger situation, he calls his wife.

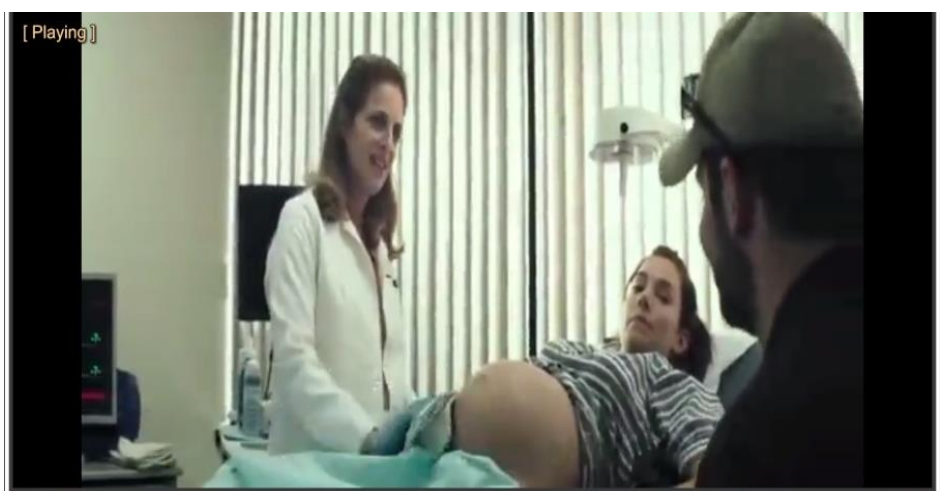

Figure 3. : The checking of Taya's pregnancy in gynecologist.

Figure 3. at 00.53.59- 00.54.25 illustrats that Chris Kyle accompanies his wife to check her pregnancy to a gynecologist. Eventhough he is a sniper of Navy SEAL who often 


\section{English Teaching Journal, Vol. 4 No. 1, Juni 2016}

ISSN: 2338-2678

does his duty in battle field, he loves his wife. The proof is he wants to accompany his wife to control her pregnancy in a doctor. It shows what kind of hero he is.

All of the figures above show the portrayal and heroic mode of Chris Kyle seen in American Sniper movie. The hero in American Sniper movie displayed as member of Navy SEAL United States who has good and strong body already happen in the movie in the past in Lone Survivor 2014. It means that from time to time the hero does not change. The purpose of the mission is to save Iraq by catching and killing the terrorist in Iraq war. It means that the purpose of the mission has changed. Movie in the past show the struggle of hero in war. This movie focuses on the catching terrorists.

The hero also has a good character to his friend. He cares and protects his friend from enemy. He is the hero who has a big nationalism by sacrificing his life to his country. The mentality of hero as good friend and has big nationalism has already happen in the past. It means that this mentality has changed. The mentality of hero as a husband and father who love his wife and his family which shown in American Sniper movie is one of new version which does not happen in the past. Eventhough he is as a hero, he is still like ordinary people. When he does his duty on the field and in danger situation he still contacts his family. It shows that this movie is more various and creative.

\section{DISCUSSION}

The discussion will start explaining the reason of displaying hero and heroic modes in American Sniper movie. The researcher explains about the relationship between the United States and Iraq war. The researcher also explains the relationship between American Sniper movie and society.

\section{Behind the American Sniper Movie}

American Sniper movie is adopted from Iraq war which is led by Saddam Hussien, but actually, the story of American Sniper is a little bit different from reality. In reality, the United States against Iraq because there is a weapon conflict between United Stated and Iraq in 2003. United States accuses Iraq makes Weapons of Mass Destruction (Buzzanco, 2008). In fact, United States can not prove that Iraq makes a Weapons of Mass Destruction. After the United States can not prove, United Stated does not leave Iraq quickly. The United States keep against Iraq in Iraq War. 
Meanwhile, American Sniper tells about a terrorist from Al-Qaeda which is led by Abu Musab al-Zarqawi. In this movie, it is told that the United States helps Iraq to find, catch, kill terrorists and bring out the terrorist from Iraq country. The movie becomes a controversy because it is reputed as United States Propaganda. This movie is released after the issue of ISIS and Al-Qaeda threat is booming. The history record believes that this is one of the propaganda United States where the United States is lead by George Walker Bush as the president of the United States. He gives the command to fight the Iraq, because Iraq breaks the resolution of PBB No. 1441 about Weapons of Mass Destruction so that the United States must stop it with violence (Hahn, 2012: 3). Thus, the United States againts Iraq without investigate it.

Before United States has disputed with Iraq, United States and Iraq has good relationship. They make cooperation. United States helps Iraq in invasion to Iran 1980. United States and United States western allies give support and fund to Iraq, one of them is make a weapon to fight Iran. In fact, the invasion in Iran does not give any result. The war between Iraq and Iran give bad result to both of them. Both of them get harm in victims and material. The bust of Iraq in invasion to Iran makes United States batrayed to Saddam Hussein.

The United States gets nothing from the invasion to Iraq so that The United States accuses Iraq that Iraq makes Weapons of Mass Destruction. Saddam Hussein uses Weapons of Mass Destruction to aagainst the Kurdish people in northern Iraq in 1988 and against the Iranian people during the Iraq-Iran War (Amir, 2014: 302). Many people reject that assumption. They say that the assumption can not be approved. According to Mearsheimer and Walt (in Amir,2014: 302), they say that they disagree with the Bush's assumption that Iraq use Weapons of Mass Destruction to againts United States, Kurds, and Iranian. Based on Security Council of PBB does not state that Iraq use Weapons of Mass Destruction. Amir (2014: 302). States that the United States has tried to check Weapons of Mass Destruction but there is not evidence. Based on the explanation above, it can be seen that the United States lies to the society in the world.

The United States can deceive the society in the world because of George Bush. $\mathrm{He}$ is President of United States who gives a command to invasion in Iraq because of Weapons of Mass Destruction and there is evidence to prove that Iraq use Weapons of 


\section{English Teaching Journal, Vol. 4 No. 1, Juni 2016}

ISSN: 2338-2678

Mass Destruction. It shows that George Bush is bad person. He takes advantages from that condition. There are many people get suffer from it such as injuy and death both in United States and Iraq.

The United States society is also fooled by George Bush. For his interest, he sends the United States army to the Iraq for his mission to attack Iraq. There are many of United States army gets injury and death. The terrible thing is that many of the United States army get depression. Many parents of them feel disagree if the United States Army send to Iraq. They do not want their son get injury and death in the battle field. They prefer their sons staying at home to going to Iraq war.

\section{The Relationship Between American Sniper Movie and Society}

The history records that Hollywood movie production began during World War II. In that era, the development of movie is more progressed where the French movies and Italy movies are more popular. Both of them are more marketable in European and international theatres. It makes the American movie industry attempt to compete by making a movie production based on the Hollywood area. Now, the American movie can be said as Hollywood movie.

American Sniper is one example of action war popular Hollywood movie. This movie is liked by society. American Sniper becomes a major success, with a worldwide gross of over $\$ 500$ million (Tartaglione, 2015). It shows that this movie is liked and favoured by people. This movie is very popular and liked by movie lovers because the story of the movie is very inspiring. It is about hero who kills many terrorist and performs as United States Navy SEAL who defends the truth. Thus, if one literary work is favoured and discussed by people, it can be included as popular literature. Adi (2011: 24) states that popular literature is the literature product that accepted by the wide society. The term "accepted" here means that it is consumed by many people which refer to the number of the sale.

Besides, the creator of American Sniper is also very creative. They make the movie became various. The creator has good concept to create a good movie. They make movie based on the true story which happen in past time. It is about Iraq war. Iraq war is one of history story which is has long history. The story is very interesting because it still happen until in this time. The reason of creator making movie which adopts from true 
story is to entertain people, catch the people interest and give more knowledge people (Hecht: 2016). The people who like American Sniper movie has the different reason. The reason can be positif and negatif. The positive reason, American Sniper shows that the hero who has big nationalism to his country. While in negative reason, the story has different story from the reality. It shows that there is propaganda in the American Sniper movie. Thus, the movie makes controversy in society in world.

The creator packs this movie in interesting way, so it can make the audience involved in the movie. American Sniper has received six nominations, including Best Picture, Best Adapted Screenplay, Best Actor for Bradley Cooper, Best Sound Editing, Top Ten Film of the Year, Best Director. It also gets award in Best Sound Editing nomination (McClintock, 2015). Getting award and being nominated, it shows that this movie has popular theme in the Hollywood movie.

The movements of the hero movie are done by Hollywood to fulfill the market need. It can be seen that the creators are more various and creative in making new production of movie. They make the action war movie are move variously. The creators also want to show many story of Hollywood movie which happens in the world. Besides, there is a secret mission of Hollywood which shows the position of United States as the security council of PBB.

\section{CONCLUSION}

This study discusses about the popular literature of American Sniper movie. The researcher analyzes the portrayal and heroic mode seen in the American Sniper movie and the reason of hero and heroic mode are represented in the American Sniper movie. The figure of hero in American Sniper movie has been performed in the previous movie. It shows that from time to time the figure of hero does not change. Then, the mentality of hero as a husband and father who love and care to the family is the new version from this movie. The movement of hero heroic mode from time to time reflects the audiences's interest or the movie lovers to the action war movie. It is also motivation for the Hollywood production to continue create the 


\section{English Teaching Journal, Vol. 4 No. 1, Juni 2016}

ISSN: 2338-2678

newest action war movie to fulfill the market request. Thus, this movie is a product of popular literature.

\section{ACKNOWLEDGEMENTS}

The researcher would like to gratitude to following persons: Mr.Basori (Alm), Mrs. Yasti (Almh), Mr. Suparman, Mrs. Siti Patoyah, and all her friends.

\section{REFERENCES}

Adi, I (2008). Mitos di balik Film Laga Amerika. Yogyakarta: Gadjah Mada University Press

Adi, I (2011). Fiksi Popular: Teori \& Metode Kajian. Yogyakata: Pustaka Belajar

Amin, Zana (2014). Why did the United States Lead an invasion of Iraq in 2003?. Academic Research Journals, $\quad$ V. 2(11), PP. 301-308, (http://www.academicresearchjournals.org/IJPSD/Index.html, taken on 23 July 2016).

Berg, B. L. (2001) Qualitative Research Methods for the social Sciences (4 ${ }^{\text {th }}$ Editions). Boston: Allynand Bacon

Bogdan, Robert C., \& Biklen, S. K. (2007). Qualitative Research for Education: An Introduction to Theory and Method (Fifth Edition). Boston: Pearson

Buzzanco, R. 8 August 2005. How did Iraq and The United States Become Enemies, History News Network, (http://historynewsnetwork.org/article/1066\#sthash.TvGzEsSk.dpuf, taken on 22 Maret 2016).

Hahn, Peter (2012).A Century of U. S. Relations with Iraq. Vol. 5, issue 7. (http/www.IRAQCentury-of-U.S.-Relations-with-Iraq-Origins-Current-Events-in-Historical-

Perspective.htm, taken 20 July 2016)

Hecht, B. 21 April 2016. How to Sell Movie Ideas to Hollywood, (http://www.How-to-SellMovie-Ideas-to-Hollywood-Early-To-Rise.htm, taken on 21 April 2016).

Karki, D. (2011). The action Hero in Popular Hollywood and Hongkong Movie. Texas: The University of Texas at Dallas

McClintock, P. 22 February 2015. “American Sniper" Snubbed at 2015 Oscars, (http://www.hollywoodreporter.com/news/american-sniper-snubbed-at-2015-776511, taken on 16 April 2016).

Tartaglione, N. 8 March 2015. 'American Sniper' Shoots Past \$500M At Global B.O.; More Eastwood Records Set, (http://deadline.com/2015/03/american-sniper-500-million-boxoffice-eastwood-warner-1201388425/, taken on 02 August 2016). 
Yin, Robert K. (2011). Qualitative Research from Start to Finish. New York and London: The Guildford Press. 